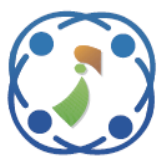

\title{
A Selection of Barrier Factors Affecting Reverse Logistics Performance of Thai Electronic Industry
}

\author{
Tossapol Kiatcharoenpol ${ }^{1 *}$ \\ Pornwasin Sirisawat ${ }^{1}$ \\ ${ }^{1}$ Faculty of Engineering, King Mongkut's Institute of Technology Ladkrabang, \\ Bangkok, Thailand 10520, \\ *Corresponding author’s Email: tossapol_k@yahoo.com
}

\begin{abstract}
The aim of research is to identify and select various significant barriers affecting Reverse Logistics (RL) performance in Thai Electronic Industry. The work utilizes Structure Equation Modeling (SEM) to empirically validate the relation of barrier to RL performance based on path analysis and Confirmation Factor Analysis (CFA) of SEM. The questionnaire to investigate barriers and RL performance are developed by using a literature review of international research works. The survey has been carried out on mostly large and medium size electronic companies with running operations more than 10 years and located in Thailand. The 67 responses can be obtained and formulate the SEM model for testing and analysis. The hypotheses were tested in which Barriers was directly, indirectly negatively associated with RL performance. After the modification of SEM model according to fit indices, it was shown that 29 barriers are found statistically significant in this empirically study. These barriers can be categorized into eight groups. Such barriers are Management barrier, Organization barrier, Product barrier, Technological barrier, Infrastructural barrier, Financial barrier, Involvement and Support barrier and Legal barrier. The research finding gives priority to enhancement in RL practices in electronic industry to establish effective RL projects as a crucial strategy to meet the environment awareness in global trends.
\end{abstract}

Keywords: Barriers, Reverse logistics, Electronic industries, Structure equation modeling.

\section{Introduction}

All In global awareness of environment due to the rapidly increasing of e-waste with responsibility to consumers, many countries and internal environmental organizations are in courage to decrease this problem to effect environment. A number of regulations are used to control by regularly reporting the quantity sold and to ensure that the products are disposed of in an environmentally friendly way. Some well-known regulations are WEEE (waste electronic and electrical equipment) to manage proper disposal and RoHS to ban some toxic substances like lead, cadmium, mercury, hexavalent chromium, PBB and PBDE used in electronics and electrical part and product. Thus, electronic manufacturing and government organization have to play attention to this trend in order to reduce the environmental problem, cost and increase competitiveness by using concept of Green supply chain (GSC). Therefore, Reverse Logistics (RL) is one of GSC management is really needed to perform effectively to deal with this work. Reverse logistics (RL) is an important process because of potentials of value recovery from the used products which RL focuses on waste management, material recovery, parts recovery or product recovery [1]. Many manufacturing companies use RL as one of key strategic activity because it can create value. The company can get more benefits from reverse logistics management such as rating additional revenue, reducing operating costs, and minimizing the opportunity costs of defective or out-of-date products [2]. The efficient management for collected waste is the development of all necessary infrastructures and also coordination of all relevant stakeholders in supply chain [3]. 
In Thailand, electronic industry plays an important role to Thailand's economic. In the year 2018 , total value of exporting electronic products was about US\$ 37 billion. The first rank of exporting product was computer parts that were about $56 \%$ of total exporting electronic products. The more manufacturing and export, the better economics for Thailand but it consequently causes a huge e-waste inside the country. Thus, the focusing on support electronic manufacturing to manage their environment matters though $\mathrm{RL}$ practices is an important issue in Thai electronic industry apart from only complying with law and environmental regulations. This research aims to investigate the impediment of implementing Reverse Logistics, although some woks have been done in these areas, but they are not specific especially in Thai electronic industry. This work employs empirical approach with Structure Equation Modeling (SEM), one of wellknown and promising research techniques. In the early part of work, the literature review of these barriers on academic research and international journal are comprehensively explored and presented in the next section. For an empirically study in Thai electronic industry, manufacturing companies are widely surveyed with a well-construct questionnaire. The obtained data are analyzed by using SEM, an effective statistical technique to testing hypotheses about relation of variables. The selection of barrier to $\mathrm{RL}$ is variables found statistically significant in Thai electronic Industry.

\section{Literature reviews}

\subsection{Barrier factors in reverse logistics}

There are a number of studies done to facilitate implementation of reverse logistics due to the increasing of environmental awareness. However, the practice of RL is still difficult for an electronic company to perform with barriers in various aspects. The literature review of barriers for implementing RL on international database are carried out and summarized in the authors' works [4-5]. Barriers are categorized into eights groups and their 37 subcriteria are shown in Table 1 associated with their references.

Table 1. Summarized barrier factors of reverse logistics

\begin{tabular}{|c|c|c|c|}
\hline Criteria & Sub-criteria & Code & References \\
\hline \multirow{6}{*}{$\begin{array}{l}\text { Management } \\
\text { Barriers (MB) }\end{array}$} & Lack of commitment by top management & MB1 & \multirow[t]{6}{*}{ [6-18] } \\
\hline & Lack of strategic planning for ensuring RL practices & MB2 & \\
\hline & Lack of awareness and understanding in RL adaptation & MB3 & \\
\hline & Lack of specific goals for environment and waste management & MB4 & \\
\hline & Lack of policies for RL practices & MB5 & \\
\hline & Company policies & MB6 & \\
\hline \multirow{5}{*}{$\begin{array}{l}\text { Organization } \\
\text { Barriers (OB) }\end{array}$} & Lack of proper organizational structure \& support for RL practices & OB1 & \multirow{5}{*}{$\begin{array}{l}{[8-12],} \\
{[14-15],} \\
{[17-20]}\end{array}$} \\
\hline & Lack of shared understanding of best practices & OB2 & \\
\hline & Lack of training \& education about RL & OB3 & \\
\hline & Lack of organization personnel resources & OB4 & \\
\hline & Lack of appropriate performance management system & OB5 & \\
\hline \multirow[t]{3}{*}{$\begin{array}{l}\text { Product } \\
\text { Barriers (PB) }\end{array}$} & $\begin{array}{l}\text { Uncertain quality and quantity of return products from point of } \\
\text { consumption }\end{array}$ & PB1 & \multirow{3}{*}{$\begin{array}{l}{[5],[8-10],} \\
{[14-15],} \\
{[17],[21]}\end{array}$} \\
\hline & Less economic value recovered & PB2 & \\
\hline & Risk of storage of hazardous materials & PB3 & \\
\hline \multirow{4}{*}{$\begin{array}{l}\text { Legal barriers } \\
\text { (LB) }\end{array}$} & Lack of enforced laws, legislation and directives for EoL products & LB1 & \multirow{4}{*}{$\begin{array}{l}{[7-10],} \\
{[11],} \\
{[13-16]}\end{array}$} \\
\hline & Lack of government supportive policies on RL practices & LB2 & \\
\hline & Lack of standard/green practices for recycling & LB3 & \\
\hline & Loopholes in Thai laws and regulations on waste management & LB4 & \\
\hline \multirow{5}{*}{$\begin{array}{l}\text { Technological } \\
\text { barriers } \\
\text { (TB) }\end{array}$} & Lack of information and technological systems for RL practices & TB1 & \multirow{5}{*}{$\begin{array}{l}{[5-10],} \\
{[12],} \\
{[15],[20]}\end{array}$} \\
\hline & Less development of recycling technologies & TB2 & \\
\hline & Lack of available technological infrastructure to adopt RL practices & TB3 & \\
\hline & Lack of technical expertise to support RL practices & TB4 & \\
\hline & Lack of flexibility to change from traditional system to new system & TB5 & \\
\hline \multirow{4}{*}{$\begin{array}{l}\text { Infrastructural } \\
\text { barriers (IB) }\end{array}$} & Lack of infrastructure facility to support RL implementation & IB1 & \multirow{4}{*}{$\begin{array}{l}\text { [8], [10], } \\
{[16-17],} \\
{[20]}\end{array}$} \\
\hline & Lack of efficient and effective systems to monitor returns and recalls & IB2 & \\
\hline & Lack of investment in RL product storage & IB3 & \\
\hline & Increase of unstandardized waste management area & IB4 & \\
\hline
\end{tabular}


Table 1. Summarized barrier factors of reverse logistics (cont.)

\begin{tabular}{|c|c|c|c|}
\hline \multirow{5}{*}{$\begin{array}{l}\text { Financial } \\
\text { barriers (FB) }\end{array}$} & Financial constraints & FB1 & \multirow{5}{*}{$\begin{array}{l}{[6-12],} \\
{[15-21]}\end{array}$} \\
\hline & High investments and less return-on-investments & FB2 & \\
\hline & Expenditure in collection and storage of used products & FB3 & \\
\hline & Cost of environmentally friendly packaging & FB4 & \\
\hline & Cost of nonhazardous and hazardous waste disposal & FB5 & \\
\hline \multirow{5}{*}{$\begin{array}{l}\text { Involvement } \\
\text { and support } \\
\text { barriers (ISB) }\end{array}$} & $\begin{array}{l}\text { Lack of coordination and collaboration with 3rd party logistics } \\
\text { providers }\end{array}$ & ISB 1 & \multirow{5}{*}{$\begin{array}{l}\text { [5-21], } \\
{[13],} \\
{[15-17],} \\
{[19],[21]}\end{array}$} \\
\hline & Lack of support of supply chain partners & ISB2 & \\
\hline & Customer perception about reverse logistics & ISB3 & \\
\hline & No proper training/ consultancy/ reward for supply chain partner & ISB4 & \\
\hline & Lack of public focus on environmental issues & ISB5 & \\
\hline
\end{tabular}

Table 2. Reverse logistics performance factors

\begin{tabular}{|c|c|c|c|}
\hline Criteria & Sub-criteria & Code & References \\
\hline \multirow[t]{3}{*}{$\begin{array}{l}\text { Green Image } \\
\text { (GI) }\end{array}$} & $\begin{array}{l}\text { Percentage of reduction of consumption of rare material/non- } \\
\text { renewable energy }\end{array}$ & GI1 & \multirow[t]{3}{*}[23-24]{} \\
\hline & $\begin{array}{l}\text { Percentage of reduction in the use of hazardous materials/ products / } \\
\text { process }\end{array}$ & GI2 & \\
\hline & Number of environmental certifications/ awards achieved & GI3 & \\
\hline \multirow{2}{*}{$\begin{array}{l}\text { Flexibility } \\
\text { (FL) }\end{array}$} & Feasibility in recycling/ repair options & FL1 & \multirow[t]{2}{*}[23-24]{} \\
\hline & Reusability of parts/ products (product modularity/ durability) & FL2 & \\
\hline \multirow{2}{*}{$\begin{array}{l}\text { Quality } \\
\text { (QA) }\end{array}$} & Percentage of defects & QA1 & \multirow[t]{2}{*}[23-25]{} \\
\hline & Customer complaints resolved & QA2 & \\
\hline \multirow{2}{*}{$\begin{array}{l}\text { Responsiveness } \\
\text { (RE) }\end{array}$} & Reduction of return rates & RE1 & \multirow[t]{2}{*}[23-25]{} \\
\hline & Reduction of total lead time for customer complaints resolved & RE2 & \\
\hline \multirow{3}{*}{$\begin{array}{l}\text { Expense } \\
(\mathrm{EX})\end{array}$} & Reverse distribution/ transportation cost & EX1 & \multirow[t]{3}{*}[23-26]{} \\
\hline & $\begin{array}{l}\text { Total cost for testing/ sorting/ repair/ refurbishment/ remarketing/ } \\
\text { redistribution inventory/ land filling/ scrapping }\end{array}$ & $\mathrm{EX} 2$ & \\
\hline & $\begin{array}{l}\text { Cost of information and communication technology (ICT) support } \\
\text { installed }\end{array}$ & EX3 & \\
\hline \multirow{3}{*}{$\begin{array}{l}\text { Value } \\
\text { Recovered } \\
\text { (VE) }\end{array}$} & Revenue from reselling repaired products in value-recovery & VA1 & \multirow{3}{*}{$\begin{array}{l}{[23-25]} \\
{[27]}\end{array}$} \\
\hline & $\begin{array}{l}\text { Cost avoidance by reusing refurbished parts in the forward supply } \\
\text { chain }\end{array}$ & VA2 & \\
\hline & Cost avoidance by recycling materials & VA3 & \\
\hline
\end{tabular}

\subsection{Reverse logistics performance}

The reverse logistics performances are also reviewed and categorized in the work of Sirisawat and Kiatcharoenpol [22]. The criteria to evaluate the performance are set into six groups with details of sub-criteria as presented in the Table 2.

The criteria are Green Image, Flexibility, Quality, Responsiveness, Expense and Value Recovered and all fifteen sub-criteria as RL performance factors, which will be used for validating significant barriers factors or variables in Thai electronic industry by using Structure Equation Modeling methodology.

\subsection{Structure equation modeling techniques}

A structure equation modeling (SEM) is a comprehensive statistical approach to testing hypotheses about relations among observed and latent variables [28]. Rigdon [29] defines SEM as a methodology for representing, estimating, and testing a theoretical network of (mostly) linear relations between variables. SEM is also be the test of hypothesized patterns of directional and nondirectional relationships among a set of observed (measured) and unobserved (latent) variables [30]. In the work Teo et al. [31] and Byrne [32], SEM is compared against other multivariate techniques and listed four unique features of SEM:

1) SEM takes a confirmatory approach to data analysis by specifying the relationships among variables a priori. By comparison, other multivariate techniques are descriptive by nature so that hypothesis testing is rather difficult to do.

2) SEM provides explicit estimates of error variance parameters. Other multivariate techniques are not capable of either assessing or correcting for measurement error. For example, a regression analysis ignores the potential error in all the independent (explanatory) variables included in a 
model and this raises the possibility of incorrect conclusions due to misleading regression estimates.

3) SEM procedures incorporate both unobserved or latent and observed variables. Other multivariate techniques are based on observed measurements only.

4) SEM is capable of modeling multivariate relations, and estimating direct and indirect effects of variables under study.

As mentioned above, SEM has ability to evaluate, approximate, stipulate and portray models to demonstrate hypothesis interrelationships between variables through non rational path diagram. It has ability to deal with non- recursive models and has effective ability to solve the real-life complex problems, which a multiple linear regression cannot model because of certain problems and violations. SEM has played significant role of applications in wide areas such as strategy planning, supply chain, process control, industrial safety and ergonomics, industrial performance, decision making and environmental impacts of manufacturing organizations. A number of applications have proven the practical benefit of the techniques [33-36].

\section{Research methodology}

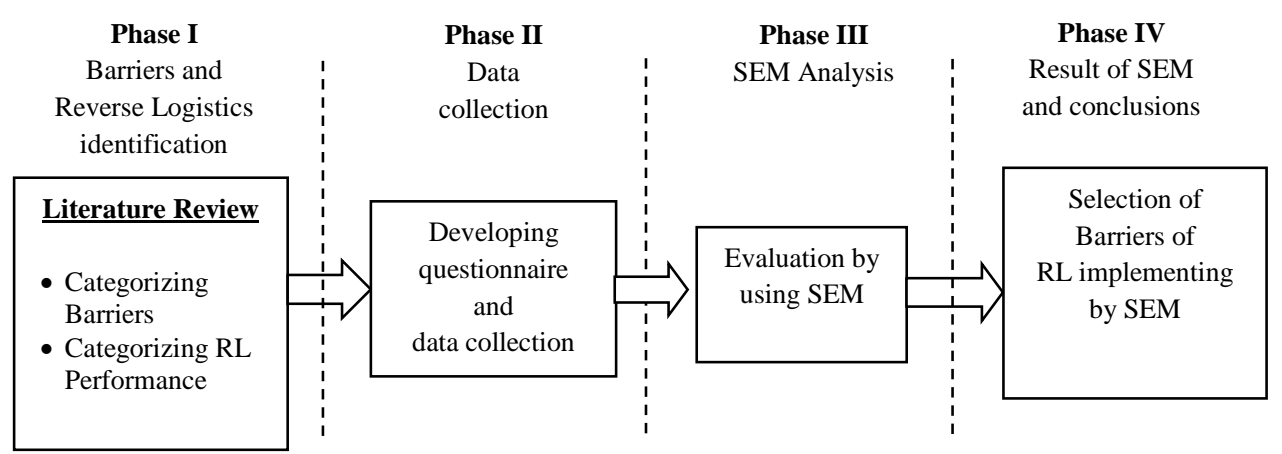

Figure. 1 Research methodology

Table 3. Demographic of respondents

\begin{tabular}{|l|l|c|}
\hline \multirow{2}{*}{ Sample Characteristic } & Percent (\%) \\
\hline \multirow{2}{*}{$\begin{array}{l}\text { Respondent's working } \\
\text { experience }\end{array}$} & Lower than 5 years & $13.43 \%$ \\
\cline { 2 - 3 } & Between 5 to 10 years & $11.94 \%$ \\
\cline { 2 - 3 } & More than 10 years & $74.63 \%$ \\
\hline \multirow{3}{*}{ Company operating year } & Lower than 5 years & $2.99 \%$ \\
\cline { 2 - 3 } & Between 5 to 10 years & $7.46 \%$ \\
\cline { 2 - 3 } & More than 10 years & $89.55 \%$ \\
\hline \multirow{3}{*}{ Number of employees } & Lower than 50 persons & $14.93 \%$ \\
\cline { 2 - 3 } & Between 50 to 150 persons & $2.99 \%$ \\
\cline { 2 - 3 } & More than 150 persons & $82.08 \%$ \\
\hline \multirow{3}{*}{ Ownership } & Thai & $28.13 \%$ \\
\cline { 2 - 3 } & Foreign-owned & $9.38 \%$ \\
\cline { 2 - 3 } & Joint venture & $62.50 \%$ \\
\hline
\end{tabular}


For the characteristic of respondents in Table 3, the majority of companies have been operating more than 10 years ( $89.55 \%$ of all respondents). The survey was dominated by foreign-owned and joint-venture companies $(71.88 \%)$. The responding companies varied in size, but a majority of the respondents employs more than 150 persons (82.08\%). It is noted that most of respondents are large and medium size companies which are mostly foreign involved ownership.

\subsection{Structure equation modeling to validate $R L$ barriers}

As per literature review and analysis of multiple regression analysis, eight independent constructs and one dependent construct namely, RL Performance (RLP) have been deployed to construct the SEM model. Fig. 2 depicts a systematic nomenclature of SEM Model deployed in present study indicating various predictors and outcome variable. It illustrates the conceptual model constructed in this research work to examine the relationships between eight barriers; Management Barrier (MB), Organization barrier (OB), Product Barrier (PB), Technological Barrier (TB), Infrastructural Barrier (IB), Financial Barrier (FB), Involvement and Support Barrier (ISB) and Legal Barrier (LB) by conducting an empirical analysis of manufacturing enterprises.

Thus, the following nine hypotheses $(\mathrm{H} 1, \mathrm{H} 2$, $\mathrm{H} 3$,.., and H9) are also proposed to examine the level of association between various barriers factors and RL performance in electronic companies. Hypothesis testings are consisted of two groups which are direct and indirect relation to RL performance.

The direct relation is :

$\mathrm{H}_{\mathrm{a}} 1$ : Reverse logistics barriers are directly negatively associated with the RL performance

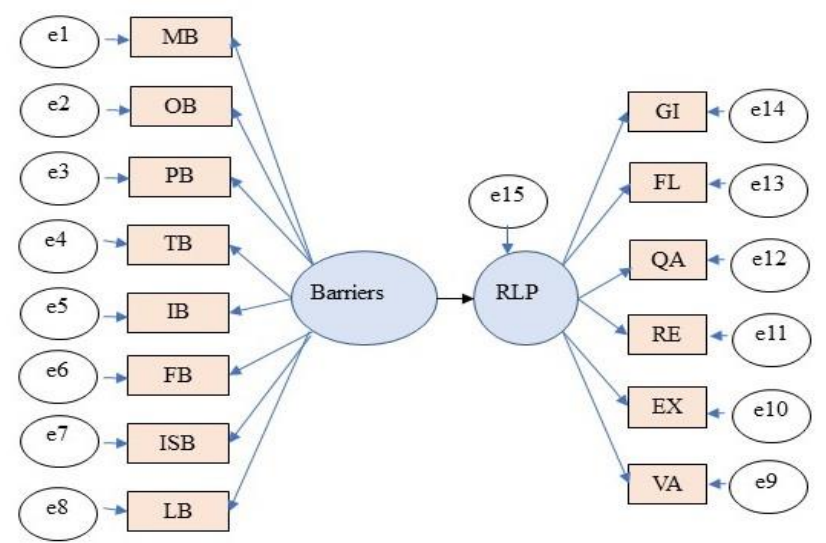

Figure. 2 SEM model for reverse logistics barriers
The indirect relations are :

$\mathrm{H}_{\mathrm{a}} 2$ : Management Barrier is indirectly negatively associated with the RL performance.

$\mathrm{H}_{\mathrm{a}} 3$ : Organization Barrier is indirectly negatively associated with the RL performance

$\mathrm{H}_{4} 4$ : Product Barrier is indirectly negatively associated with the RL performance

$\mathrm{H}_{\mathrm{a}}$ 5: Technological Barrier is indirectly negatively associated with the RL performance.

$\mathrm{H}_{\mathrm{a}} 6$ : Infrastructural Barrier is indirectly negatively associated with the RL performance.

$\mathrm{H}_{\mathrm{a}}$ 7: Financial Barrier is indirectly negatively associated with the RL performance.

$\mathrm{H}_{\mathrm{a}}$ 8: Involvement and Support Barrier is indirectly negatively associated with the RL performance.

$\mathrm{H}_{\mathrm{a}}$ 9: Legal Barrier is indirectly negatively associated with the RL performance.

\section{Analysis and results}

\subsection{Reliability of collected data}

The data obtained from various manufacturing organizations through a questionnaire was tested to certain necessary techniques for testing like 'Cronbach's $\alpha$ ' to evaluate data reliability before SEM has been employed. Based on the higher value suggest the higher internal consistent, all values are recommended more than 0.70 to indicate enough reliability [37]. The Cronbach's $\alpha$ 'of Barrier factors and RL performance are presented in Table 4 and 5, respectively. It should be noted that all data obtained in this study have adequate reliability.

Table 4. Reliability test of barriers data

\begin{tabular}{cc}
\hline Barrier Factors & Cronbach's alpha $(\alpha)$ \\
\hline MB & 0.937 \\
OB & 0.877 \\
PB & 0.901 \\
LB & 0.862 \\
TB & 0.957 \\
IB & 0.891 \\
FB & 0.931 \\
ISB & 0.859 \\
\hline
\end{tabular}

Table 5. Reliability test of RL performance data

\begin{tabular}{cc}
\hline RL Performance & Cronbach's alpha $(\alpha)$ \\
\hline GI & 0.861 \\
FL & 0.932 \\
QA & 0.757 \\
RE & 0.895 \\
EX & 0.750 \\
VA & 0.929 \\
\hline
\end{tabular}




\subsection{Analysis of SEM model}

A complete SEM Model exhibited in Fig. 3 has been developed by utilizing the AMOS software for evaluating the relationships amongst various attributes involved in the research. The study presents the linkage of independent constructs with regression coefficients in an unstandardized SEM model. The path analysis diagram for the constructs and refined variables with regression coefficients in the model as depicted in Fig. 3, demonstrates relation between Barriers and RL performance in the empirical study of Thai electronic industry.

For model testing, the fit indices are calculated as displayed in Table 6. It shows that values of CMIN/DF (3.361) > 2, Goodness of Fit Index (GFI $=.641)<0.95$, Root Mean Square Error Approximation $($ RMSEA $=.189)>0.05$ and P-value $<0.05$.

These indices point out that the first trial of SEM model is not consistency. An improvement can be made by applying the modification index (MI) values for covariance and regression weight for some factors including reduction of a few of barrier factors to increase correlation of observed data that make model acceptable.

\subsection{Modification of SEM model and results}

Fig. 4 depicts the modification of the original SEM model. MI describes changes in structure of the

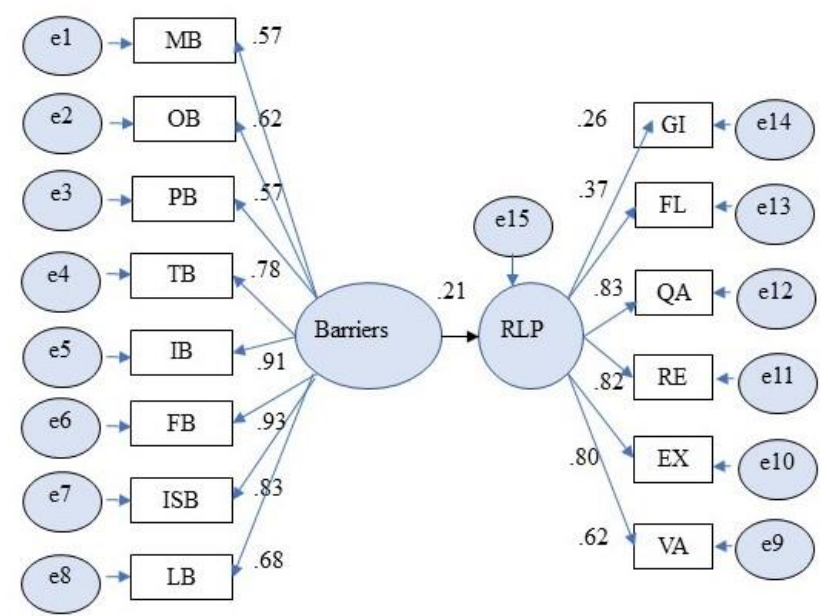

Figure. 3 Path diagram for relation between barrier and RL performance

Table 6. Fit indices of SEM model

\begin{tabular}{lccc}
\hline Model & CMIN & DF & P \\
\hline Default & 255.434 & 76 & .000 \\
\cline { 2 - 4 } Model & CMIN/DF & GFI & RMSEA \\
\cline { 2 - 4 } & 3.361 & .641 & .189 \\
\hline
\end{tabular}

model and demonstrates improvements in fit, presented by incorporating specific additional relationships in SEM model.

The selection of MI should be made based on threshold values to reduce the display of MI to a smaller set. The fit indices of modified SEM model and its values have been presented in Table 7 .

The CMIN/DF $(1.306)<2$, Goodness of Fit Index $(\mathrm{GFI}=.898)<0.95$ and Root Mean Square Error Approximation (RMSEA $=.068)>0.05$ are in the range of acceptable criteria. Therefore, these all fit indices associated with $\mathrm{P}$-value $>0.05$ indicate the modified model is sound and applicable for this work. The analysis of hypothesis testing of the modified SEM model can be reliably obtained. The results from AMOS demonstrated in Table 8 show that relations of barriers to RL performance are statistically significant at alpha 0.10 both in direct and indirect relations.

\subsection{Selection of barriers to RL performance}

Using SEM technique to identify significant barriers to RL performance of Thai electronic Industry, the selections are listed in Table 9 comprising of 29 barriers in similar eight groups.

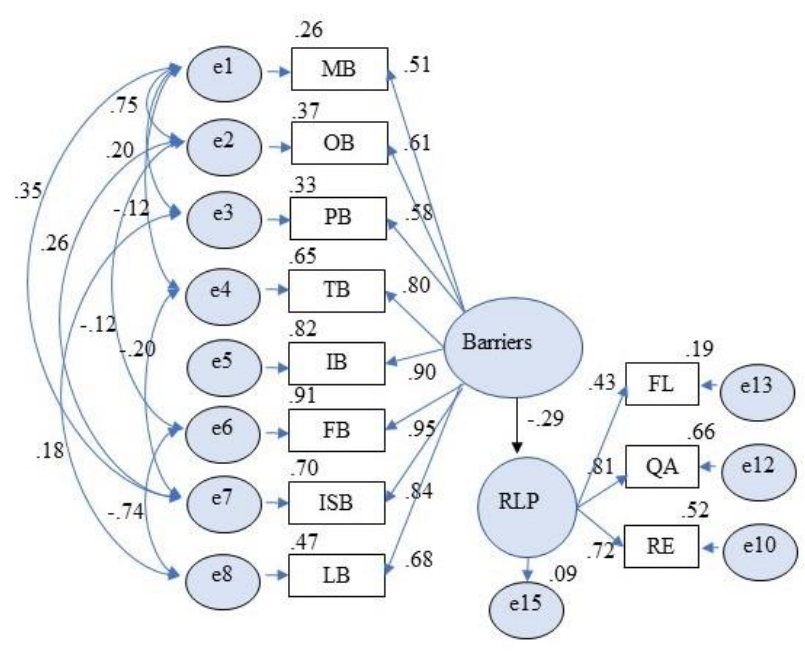

Figure. 4 Modified of SEM model

Table 7. Fit indices of the modified SEM model

\begin{tabular}{lccc}
\hline Model & CMIN & DF & P \\
\hline Modified & 44.418 & 34 & .109 \\
\cline { 2 - 4 } Model & CMIN/DF & GFI & RMSEA \\
\cline { 2 - 4 } & 1.306 & .898 & .068 \\
\hline
\end{tabular}


Table 8 . Results of hypothesis testing

\begin{tabular}{|c|c|c|c|c|}
\hline Null Hypothesis & $R^{2}$ & Estimate & $P$-value & Accept/Reject \\
\hline $\begin{array}{l}\mathrm{H}_{0} 1 \text { Reverse logistics barriers are not directly } \\
\text { negatively associated with RL performance. }\end{array}$ & 0.086 & -0.293 & $0.057^{*}$ & Rejected \\
\hline $\begin{array}{l}\mathrm{H}_{0} 2 \text { Management barrier is not indirectly } \\
\text { negatively associated with RL performance. }\end{array}$ & 0.264 & 0.514 & $* * *$ & Rejected \\
\hline $\begin{array}{l}\mathrm{H}_{0} 3 \text { Organization barrier is not indirectly } \\
\text { negatively associated with RL performance. }\end{array}$ & 0.369 & 0.608 & $* * *$ & Rejected \\
\hline $\begin{array}{l}\mathrm{H}_{0} 4 \text { Product barrier is not indirectly negatively } \\
\text { associated with RL performance. }\end{array}$ & 0.334 & 0.578 & $* * *$ & Rejected \\
\hline $\begin{array}{l}\mathrm{H}_{0} 5 \text { Legal barrier is not indirectly negatively } \\
\text { associated with RL performance. }\end{array}$ & 0.469 & 0.685 & $* * *$ & Rejected \\
\hline $\begin{array}{l}\mathrm{H}_{0} 6 \text { Technological barrier is not indirectly } \\
\text { negatively associated with RL performance. }\end{array}$ & 0.647 & 0.805 & $* * *$ & Rejected \\
\hline $\begin{array}{ll}\mathrm{H}_{0} 7 \text { Infrastructural barrier is not indirectly } \\
\text { negatively associated with RL performance. }\end{array}$ & 0.816 & 0.903 & $* * *$ & Rejected \\
\hline $\begin{array}{l}\mathrm{H}_{0} 8 \text { Financial barrier is not indirectly negatively } \\
\text { associated with RL performance. }\end{array}$ & 0.909 & 0.954 & $* * *$ & Rejected \\
\hline $\begin{array}{l}\mathrm{H}_{0} 9 \text { Involvement and support barrier is not } \\
\text { indirectly negatively associated with RL } \\
\text { performance. }\end{array}$ & 0.698 & 0.836 & $* * *$ & Rejected \\
\hline
\end{tabular}

$*$ P-value $\leq 0.10, * * *$ The $\mathrm{P}$-value $\leq 0.001$

Table 9. Selection of RL barriers

\begin{tabular}{|c|c|}
\hline Groups & Barriers \\
\hline \multirow[t]{5}{*}{ Management Barriers } & 1. Lack of commitment by top management \\
\hline & 2. Lack of strategic planning for ensuring RL practices \\
\hline & 3. Lack of awareness and understanding in RL adaptation \\
\hline & 4. Lack of specific goals for environment and waste management \\
\hline & 5. Lack of policies for RL practices \\
\hline \multirow[t]{3}{*}{ Organization Barriers } & 6. Lack of proper organizational structure \& support for RL practices \\
\hline & 7. Lack of training \& education about RL \\
\hline & 8. Lack of organization personnel resources \\
\hline \multirow[t]{3}{*}{ Product Barriers } & 9. Uncertain quality and quantity of return products from point of consumption \\
\hline & 10.Less economic value recovered \\
\hline & 11.Risk of storage of hazardous materials \\
\hline \multirow[t]{3}{*}{ Legal barriers } & 12.Lack of enforced laws, legislation and directives for EoL products \\
\hline & 13.Lack of government supportive policies on RL practices \\
\hline & 14.Loopholes in Thai laws and regulations on waste management \\
\hline \multirow[t]{4}{*}{ Technological barriers } & 15.Lack of information and technological systems for RL practices \\
\hline & 16.Lack of available technological infrastructure to adopt RL practices \\
\hline & 17.Lack of technical expertise to support RL practices \\
\hline & 18.Lack of flexibility to change from traditional system to new system \\
\hline \multirow[t]{3}{*}{ Infrastructural barriers } & 19.Lack of infrastructure facility to support RL implementation \\
\hline & 20.Lack of efficient and effective systems to monitor returns and recalls \\
\hline & 21.Increase of unstandardized waste management area \\
\hline \multirow[t]{5}{*}{ Financial barriers } & 22. Financial constraints \\
\hline & 23.High investments and less return-on-investments \\
\hline & 24. Expenditure in collection and storage of used products \\
\hline & 25.Cost of environmentally friendly packaging \\
\hline & 26. Cost of nonhazardous and hazardous waste disposal \\
\hline \multirow{3}{*}{$\begin{array}{l}\text { Involvement and } \\
\text { support barriers }\end{array}$} & 27.Lack of coordination and collaboration with 3rd party logistics providers \\
\hline & 28.Lack of support of supply chain partners \\
\hline & 29. Lack of public focus on environmental issues \\
\hline
\end{tabular}




\section{Conclusion}

In the study, the aim is to identify essential barriers to implementing reverse logistics in Thai electronic industry. Firstly, based on the research works on the international journal and academic database, barriers for RL have been comprehensively investigated. Then the empirical study is applied in the electronic companies in Thailand with using Structure Equation Modeling Technique as a sophisticate tool to validate statistically significant of the Barriers. The SEM model has been fabricated using AMOS software to validate 37 barrier factors in the eight groups. For the first trial model, it was shown that the model cannot be fit with the empirical data. The modification is needed to adjusting the values of Modification Index for covariance and regression weight including cut off some of barriers.

After adjustment until the proposed model is fit, the analysis result presents the significant barriers of Thai electronic industry to implementing RL in this empirical work. They comprise 29 barriers within the same eight groups, which are Management Barrier (MB), Organization barrier (OB), Product Barrier (PB), Technological Barrier (TB), Infrastructural Barrier (IB), Financial Barrier (FB), Involvement and Support Barrier (ISB) and Legal Barrier (LB). The detail and explanation of barriers are described in the Section 4, Analysis and Results. However, manufacturings have to understand the situation of RL practices and barriers of their own and the findings of this research as mentioned above can be a guideline for creating suitable policies and strategies for improving efficiency of RL performance.

For further study, a set of practices to solve these significant barriers are needed to be precisely investigated. The effect of solutions to barriers studied specifically in the field work of Thai electronic industry would be the benefices of manufacturing firms to promote their Green supply chain.

\section{Acknowledgments}

This work is supported by Faculty of Engineering, King Mongkut's Institute of Technology Ladkrabang under the contract number 2562-0201018.

\section{References}

[1] S. Pokharel and A. Mutha, "Perspectives in reverse logistics: A review", Resources, Conservation and Recycling, Vol. 53, No. 4, pp. 175-182, 2009.

[2] C. Y.Chiou, H.C. Chen, C. T. Yub and C. Y. Yeh, "Consideration Factors of Reverse
Logistics Implementation -A Case Study of Taiwan's Electronics Industry", In: Proc. of the 2012 International (Spring) Conference on Asia Pacific Business Innovation and Technology Management. Procedia - Social and Behavioral Sciences, Vol.40, 2012.

[3] Ch. Achillas, Ch. Vlachokostas, D. Aidonis, N. Moussiopoulos, E. Iakovou and G. Banias, "Optimising reverse logistics network to support policy-making in the case of Electrical and Electronic Equipment", Waste Management, Vol. 30, No. 12, pp. 2592-2600, 2010.

[4] P. Sirisawat and T. Kiatcharoenpol, "A study of correlation for reverse logistics barriers to solutions using structural equation modeling", International Journal of Productivity and Quality Management, Vol.26, No. 2, pp. 139-159, 2019.

[5] P. Sirisawat and T. Kiatcharoenpol, "Correlation of Barriers to Reverse Logistics Performance Using Structural Equation Modeling", In: Proc. of IEEE International Conference on Industrial Engineering and Engineering Management, 2016.

[6] V. Ravi and R. Shankar, "Analysis of interactions among the barriers of reverse logistics", Technological Forecasting \& Social Change, Vol. 72, No. 4, pp. 1011-1029, 2005.

[7] K. Mathiyazhagan, K. Govindan, A. NoorulHaq, and Y. Geng, "An ISM approach for the barrier analysis in implementing green supply chain management", Journal of Cleaner Production, Vol. 47, pp. 283-297, 2013.

[8] C. Prakash and M.K. Barua, "Integration of AHP-TOPSIS method for prioritizing the solutions of reverse logistics adoption to overcome its barriers under fuzzy environment", Journal of Manufacturing Systems, Vol. 37, pp. 599-615, 2015.

[9] S.K. Sharma, B.N. Panda, S. Mahapatra, and S. Sahu, "Analysis of Barriers for Reverse Logistics: An Indian Perspective", International Journal of Modeling and Optimization, Vol. 1, No. 2, pp. 101-106, 2011.

[10] A. Jindal, K. S. Sangwan, "Development of an interpretive structural model of barriers to reverse logistics implementation in Indian industry", In: Proc. of the 18th CIRP International Conference on Life Cycle Engineering, 2011.

[11] A.V.D. Wiel, B. Bossink, and E. Masurel, "Reverse logistics for waste reduction in cradleto cradle oriented firms", International Journal of Technology Management, Vol. 60, No.1/2, pp. 96-113, 2012. 
[12] S.A. Zaabi, N.A. Dhaheri, and A. Diabat, "Analysis of interaction between the barriers for the implementation of sustainable supply chain management", International Journal of Advanced Manufacturing Technology, Vol. 68, pp. 895-905, 2013.

[13] Price water house Coopers, "Reverse Logistics", Integrated Supply Chain Solutions, 2008.

[14] N.A. Abdulkabir, F.S. Shaufique, A.R. Azmawani, and H. L. Siong, "The role of local content policy in local value creation in Nigeria"s oil industry: A structural equation modeling (SEM) approach", Resources Policy, Vol. 49, pp. 61-73, 2016.

[15] K. Govindan, M. Kaliyan, D. Kannan, and A.N. Haq, "Barriers analysis for green supply chain management implementation in Indian industries using analytic hierarchy process", International Journal of Production Economics, Vol. 147, pp. 555-568, 2014.

[16] M.D. Abdulrahman, A. Gunasekaran, and N. Subramanian, "Critical barriers in implementing reverse logistics in the Chinese manufacturing sectors", International Journal of Production Economics, Vol. 147, pp. 460-471, 2014.

[17] P. Yacob, "Barriers to Reverse Logistics Practices in Malaysian SMEs", International Journal of Academic Research in Economics and Management Sciences, Vol. 1, No. 5, pp. 204-214, 2012.

[18] D.S. Rogers and R.S. Tibben-Lembke, "An Examination of Reverse Logistics Practices", Journal of Business Logistics, Vol. 22, No.2, pp. 129-148, 2001.

[19] S. Luthra, V. Kumar, S. Kumar, and A. Haleem, "Barriers to implement green supply chain management in automobile industry using interpretive structural modeling technique-An Indian perspective", Journal of Industrial Engineering and Management, pp. 231-257, 2011.

[20] S. Pumpinyo and V. Nitivattananon, "Investigation of Barriers and Factors Affecting the Reverse Logistics of Waste Management Practice: A Case Study in Thailand", Sustainability, Vol. 6, pp. 7048-7062, 2014.

[21] S. Rahman and N. Subramanian, "Factors for implementing end-of-life computer recycling operations in reverse supply chains", International Journal of Production Economics, Vol. 140, pp. 239-248, 2012.

[22] P. Sirisawat and T. Kiatcharoenpol, "Correlation of Reverse Logistics Performance to Solutions Using Structural Equation
Modeling", Journal of Advance Manufacturing System, Vol. 18, No. 4, pp. 511-525, 2019.

[23] K.K. Damghani, M. Tavana, and M. Najmodin, "Reverse logistics and supply chains: A structural equation modeling investigation", International Journal of Industrial Engineering, Vol. 22, No.3, pp. 354-368, 2015.

[24] K. S. Yogi, "Performance evaluation of reverse logistics: A case of LPG agency", Cogent Business \& Management, Vol. 2, No. 1, pp.1-17, 2015.

[25] A. Agrawal and V. Choudhary, "Reverse logistics: Performance measures and their effect in product lifecycle", International Journal of Core Engineering \& Management, Vol. 1, No. 2, pp. 14-22, 2014.

[26] E. Olugu and K. Y. Wong, "Fuzzy logic evaluation of reverse logistics performance in the automotive industry", Scientific Research and Essays, Vol. 6, No.7, pp. 1639-1649, 2011.

[27] M. Bansia, J.K. Varkey, and S. Agrawal, "Development of a reverse logistics performance measurement system for a battery manufacturer", Procedia Materials Science, Vol.6, pp. 1419 - 1427, 2014.

[28] R. Hoyle, "The structural equation modeling approach: Basic concepts and fundamental issues. In R. H. Hoyle (Ed.)", Structural Equation modeling: Concepts, issues, and applications, pp. 1-15, 1995.

[29] E.E. Rigdon, Structural equation modeling. In Modern methods for business research, G. A. Marcoulides (editor). Mahwah, NJ: Lawrence Erlbaum Associates, Publishers, pp. 251-294. 1998.

[30] R. C. MacCallum, "Model specification: Procedures, strategies, and related issues", Structural equation modeling: Concepts, issues, and applications, R. H. Hoyle (editor). Thousand Oaks, CA: Sage Publications, Inc., pp. 16-29, 1995.

[31] T. Teo, L. T. Tsai, and C. Yang, Structural Equation Modeling in Educational Research and practice, pp. 3-21, 2013.

[32] B. M. Byrne, Structural Equation Modeling with AMOS: Basic Concepts, Applications, and Programming, Mahwah, NJ: Lawrence Erlbaum Associates, 2001.

[33] C. Kamuran, K. Sultan, and E. Dilek, "Development of Instrument of Bullying Behaviors in Nursing Education based on Structured Equation Modeling", Asian Nursing Research, Vol. 12, No. 4, pp. 245-250, 2018.

[34] G. Bosseluta, J. Heuze, O. Castroa, E. Fourquereauc, and S. Chevalierc, "Using 
Exploratory Structure Equation Modeling to validate a new measure of cohesion in the university classroom setting: The University Group Environment Questionnaire (UGEQ)" International Journal of Educational Research, Vol. 89, pp. 1-9, 2018.

[35] A. Singla, I. S. Ahuja, and A.P.S. Sethi, "Validation of technology push strategies for achieving sustainable development in manufacturing organizations through Structural Equation Modelling”, World Journal of Science, Technology and Sustainable Development, Vol. 15, No. 1, pp. 72-93, 2017.

[36] J. S. Randhawa and I. S. Ahuja, "Structural equation modelling for validating impact of $5 \mathrm{~S}$ implementation on business excellence of manufacturing organizations", International Journal of Quality \& Reliability Management, Vol. 34, No. 9, pp. 1592-1615, 2017.

[37] A. R. Abbas, "Effects of human resource management on hotel performance using structural equation modelling", Computers in Human Behavior, Vol. 43, pp. 293-303, 2015. 